provided a unique opportunity to examine mechanisms of toxicity (using in situ water) by means of a largescale experiment at the hatchery itself. In order to assess the relative impact on the fish of a number of water constituents such as heavy-metals and organic materials, a variety of dosing chemicals were employed within the hatchery. Fish tissue and blood samples were collected for histological and chemical analysis, respectively.

It was concluded that a combination of manganese and organic material (probably humic in nature) in reduced chemical states in discharges of bottom (hypolimnetic) waters of the impoundment during periods of minimum power-generation was responsible for the mortality. Parallels between the fish-kill under investigation and other reported causes of hypolimnetic water toxicity were also drawn. It would appear that the redox state and nature of organic materials present may control the mechanisms in the various fish-kill situations. Implications for other users of the water are currently under investigation in an expanded programme.

\section{References}

APHA [\& AWWA, WPCF] (1976). Standard Methods for the Examination of Water and Wastewater, 14th Edition. American Public Health Association, Washington, D.C.: xxxix $+1,193 \mathrm{pp}$.

Brenner, F. J., Cor bett, S. \& Shertzer, R. (1976). Effect of ferric hydroxide suspensions on blood chemistry in the Common Shiner, Notropus cornutus. Trans. Am. Fish. Soc., 3, pp. 450-5.

DiJK, H. VAN (1959). Zur Kenntnis der Basenbindung von Huminsaueren. Z. Pflanz. Dueng. Bod., 84, pp. 150-5.

DUIN, P. J. VAN (1973). Poisoning of electrodialysis membranes. Pp. 253-9 in Fourth International Symposium on Fresh Water from the Sea, Volume 3 (Ed. A. Delhannis \& E. Delhannis). [Not available for checking.]

Gilmour, J. T. \& Coleman, N. T. (1971). Buffer curves and acid strength of humic acid and two resins. Proc. Soil Soc. Am., 35 pp. 710-4.
Guessing, E. T. (1976). Physical and Chemical Characteristics of Aquatic Humus. Ann Arbor Science Publishers, Ann Arbor, Michigan: vii $+120 \mathrm{pp}$.

IngoLs, R. S. (1976). The Cause of Trout Fish-kills Occurring in the Water from the Aerated Hypolimnion of Deep Lakes. Engineering Experiment Station, Georgia Institute of Technology, Atlanta, Georgia 30582: Report ERC-0176, 45 pp.

Irwin, W. H., Symons, J. M. \& Roвeck, G. G. (1967). Water quality in impoundments and modifications from destratification. Pp. 130-52 in Reservoir Fishery Symposium, American Fisheries Society, New York, N.Y.: viii + 569 pp.

Lu, James C. \& Chen, K. Y. (1977). Migration of trace metals in interfaces of sea-water and polluted surficial sediments. Env. Sci. Tech., 11(2), pp. 174-82.

Mukherjee, S. K. \& Basu, S. N. (1971). Study of ph and Eh changes of waterlogged soil and in pure systems. $J$. Ind. Soil Sci., 19(2), pp. 197-202.

Nix, J. F. (1967). Manganese in the Water-supply of Greers Ferry National Hatchery, Heber Springs, Arkansas. Report to the Bureau of Sport Fisheries and Wildlife [not available for checking].

Odum, E. P. (1971). Fundamentals of Ecology (3rd edition). W. B. Saunders, Philadelphia, Pennsylvania: xiv +574 pp., illustr.

Schnitzer, M. \& Khan, S. U. (1972). Humic Substances in the Environment. Marcel Dekker, New York, N.Y.: vii + 327 pp.

Swift, R. S. \& Posner, A. M. (1972). Autoxidation of humic acid under alkaline conditions. J. Soil Sci, 23(4), pp. 381-93.

U.S. Environmental Protection Agency (1975). National Eutrophication Survey: Working Paper Series. Report on Lake Sidney Lanier-Dawson, Forsyth, Gwinnett, Hall, and Lumpkin, Counties, Georgia-EPA, Region IV. Working Paper No. 293, Pacific Northwest Environmental Research Laboratory, June, 52 pp.

VISSER, S. A. (1964). Oxidation-reduction potentials and capillary activities of humic acids. Nature (London), 204, p. 581.

VISSER, S. A. (1973). Some biological effects of humic acids in the rat. Act. Biol. Med. Germ., 31, pp. 569-81.

Zitko, P., Carson, W. V. \& Carson, W. G. (1973). Prediction of incipient lethal levels of copper to juvenile Atlantic Salmon in the presence of humic acid by cupric electrode. Bull. Env. Cont. Tox., 10(5), pp. 265-71.

\title{
Introduction to the World Climate Programme
}

The subject of climate has acquired a sense of immediacy for a variety of reasons, and this fact has not gone unnoticed by the nations of the world. Encouraged by the United Nations' General Assembly, the World Meteorological Organization (WMO), headquartered in Geneva, is in the process of developing a World Climate Programme (WCP). In doing so the WMO is, of course, working closely with other international organizations concerned with climaterelated matters-most notably the United Nations Environment Programme (UNEP), the Food and Agriculture Organization (FAO), the United Nations Educational, Scientific, and Cultural Organization(UNESCO), the World Health Organization (WHO), and the non-governmental International Council of Scientific Unions (ICSU) and its Special Committee on Problems of the Environment (SCOPE).

The WMO's Executive Committee, meeting in June 1978, endorsed the concept of having a World Climate Pro- gramme, and it will be considered for official adoption by the next WMO Congress, which meets in May 1979. If it is adopted, there will be for the first time an international programme devoted to obtaining a better grasp of the problems associated with climate-including its changes, its variations, and its many impacts on human activities.

Before describing the World Climate Programme as it is now conceived, some background details would be useful. Obviously, climate has been a vital factor in the evolution of mankind and his society from the very beginning, and so the subject is by no means a new one. When the International Meteorological Organization was created in 1873, the acquisition of information on climate was one of its major concerns, and the WMO has inherited those same concerns along with others connected with the current weather and weather forecasting.

Three things have transpired in the last decade or two to push the subject of climate to the forefront in the meteo- 
rological community. A most practical matter is the realization that, in spite of our increasing technology, a world with an ever-increasing population and demand for food and other resources is more vulnerable to short-term variations or longer-term changes in climate than ever before. This was demonstrated by, for example, the crisis in the world grain market that was brought about by the partial failure of the Soviet Union's wheat crop in 1972, and the widespread suffering in the Sahel region of Africa during the drought that lasted from about 1968 to 1973. Our 'margin of safety' in world food production is shrinking, and climatic variations or changes now create international problems as never before.

The second realization which is causing some concern is the fact that mankind himself is already an important factor in the delicate and shifting balance of forces that determines our planet's climate, and will be an ever-increasing factor as we escalate our use of energy and changes in our use of land. For example, it is generally recognized that adding carbon dioxide to the atmosphere from burning fossil fuels will continue to raise the concentration of this trace-gas in our atmosphere, and that this will tend to cause a general warming due to its absorption of infrared radiation from the Earth that would otherwise escape to space - the so-called 'greenhouse effect'. Never in the history of civilization has mankind been faced with the predictable prospect of a global change of climate, and one moreover that is of his own making.

The third realization is the more encouraging one that scientists and administrators have demonstrated that they can and indeed must work together effectively on international research programmes to study the planetary system which controls our climate-the atmosphere, the oceans, the land surfaces, the ice and snow of the polar regions, living systems, and the sun. The best demonstration of this is the Global Atmospheric Research Programme (GARP), which is jointly sponsored by WMO and ICSU, and is proving to be a highly successful international programme to increase our knowledge of the geophysical factors controlling the weather and climate.

Returning now to the proposed World Climate Programme, it is conceived as having three component parts. These are:

- Climate Data and Applications Programme,

- Programme for the Study of Impacts of Climate on Human Activities, and

- Programme for Research on Climatic Change and Variability.

These will now be briefly explained in turn.

\section{Data and Applications Programme}

The proper acquisition and management of climatic data will be an essential part of the WCP, as both research and applications of the knowledge of climate depend on having good data. The WMO already sponsors the World Weather Watch (WWW), which is the global system for exchanging weather information in real time; the WMO and UNEP are together organizing and sponsoring the Global Environmental Monitoring Network (GEMS); the WMO and UNESCO have together organized the Historical Sea Surface Temperature Data (HSSTD) Project and marine climatological summaries; the WMO is actively engaged in the acquisition and management of hydrological data, and so forth-consequently very many climatic data are already on hand. However, many of the needs for data for climate research and applications are not being adequately met with the current programmes, and so steps to improve this situation will be taken.

The applications of knowledge of climate to immediate problems will also be a part of this component of the WCP. Here the emphasis will probably be on assisting developing countries with their planning of climate-sensitive projects related to agriculture, water resources, and land-use.

\section{Study of Impacts Programme}

It is clear that climatic variability (from year to year) and climatic change (from decade to decade) have impacts on a wide variety of human activities, including agriculture and forestry, water resources, land-use planning, energy planning, transportation, tourism, and so forth. Such climatic impacts can only be analyzed by taking into account the regional economic and social structures, as the impacts must be expressed in human terms.

The techniques used in such studies are still being explored, and the purpose of this Programme is to encourage such studies by bringing together interdisciplinary teams and helping them to obtain the necessary data. Though such studies will ordinarily be carried out on a regional basis, the overall emphasis will be on world problems and with a longer time-horizon than in the applications programme described earlier.

\section{Climatic Change Research Progra mme}

The purpose of this Programme is to increase our knowledge of the physical processes governing climate, and to provide a basis for defining the sensitivity of the climatic system to external changes-whether these be natural or induced by mankind. This is now a part of the GARP, and the foundations for such a programme have already been laid.

The GARP is jointly sponsored by the WMO and ICSU, and this arrangement has worked so well on the whole that a new agreement is being sought to continue it.

Those are, in brief, the three component programmes of the World Climate Programme. Between now and the meeting of the WMO Congress of May 1979, they will be considered at a series of informal planning meetings, and the evolutionary process by which they will be implemented will be worked out in detail. In February 1979 there will be a World Climate Conference, ${ }^{*}$ to be held in Geneva, at which invited experts and some 24 overview speakers will further define the state of our knowledge of the physical factors governing climate and the impacts of climatic variability and change on society-with emphasis on the latter. The first week of this Conference (12-16 February), during which the overview papers will be presented, will be open to a larger audience, and invitations for that occasion can be requested from the Secretary-General of the WMO.*

\author{
William W. Kellogg \\ World Meteorological Organization Secretariat \\ Case Postale No. 5 \\ 1211 Geneva 20 \\ Switzerland.
}

* See the 'important prospect' account by the Chairman of the Conference, Dr Robert M. White, published on page 312 of this issue. $-\mathrm{Ed}$. 